\title{
An On-Campus Homeless Shelter: The Sociological Imagination, Service-Learning, and Applied Sociology
}

\author{
Kathy Shepherd Stolley ${ }^{1}$
}

This paper provides a case study of a unique approach to teaching about homelessness - an on-campus winter emergency homeless shelter. This shelter provides an innovative and engaging pedagogical model tying together Mills' concept of the sociological imagination, service-learning, and applied sociology. Examples illustrate various aspects of Mills' perspective including: breaking down "us" and "them" boundaries; an understanding of structural issues; sociological praxis; making linkages and various levels of analysis; and opportunities for engaging wider audiences in the sociological perspective. [Article copies available for a fee from The Transformative Studies Institute. E-mail address: journal@transformativestudies.org Website: http://www.transformativestudies.org (02011 by The Transformative Studies Institute. All rights reserved.]

KEYWORDS: Sociological Imagination, Homelessness, ServiceLearning, Public Sociology, Applied Sociology

Understanding and addressing homelessness is challenging, especially for students who are just learning sociological concepts and perspectives. This paper provides a case study of one innovative approach to teaching about homelessness - an on-campus winter emergency homeless shelter. Hosting a homeless shelter provides a novel and engaging model tying together theory, service-learning, and applied sociology. The project is, at its very core, social theory in action as students learn to develop and apply their sociological imagination.

\footnotetext{
${ }^{1}$ Kathy Shepherd Stolley, PhD, is Batten Associate Professor of Sociology and Coordinator of the Women's and Gender Studies program at Virginia Wesleyan College. Her focus is applied sociology and her courses often incorporate service-learning projects involving community partners. Stolley was the 2009 recipient of her school's distinguished teaching award. She is author of The Basics of Sociology (2005), co-editor of The Praeger Handbook of Adoption (2006), and co-author of a volume on HIV/AIDS (2009). She is currently co-authoring a book on the topic of medical tourism. Address correspondence to: Kathy Shepherd Stolley, Virginia Wesleyan College, 1584 Wesleyan Drive, Norfolk, Virginia 23502; e-mail: kstolley@vwc.edu.
} 